\title{
Da produção ao mercado: "delitos económicos”, penas e controlo municipal na Idade Média, segundo o testemunho dos Costumes e Foros portugueses
}

\author{
Maria Alice da Silveira Tavares* \\ Universidade Nova de Lisboa, Lisboa, Portugal
}

\section{RESUMO}

Este texto tem como objetivo principal fazer uma reflexão sobre conflitos e os "delitos económicos", bem como os mecanismos de controlo penal e social ao dispor dos concelhos medievais portugueses (Alfaiates, Castelo Bom, Castelo Melhor, Castelo Rodrigo, Guarda, Santarém, Torres Novas, Évora e Beja) para regulamentar os setores económicos, defendendo as suas populaçôes e garantindo-lhes o abastecimento de produtos e de gêneros alimentares indispensáveis no dia a dia, a partir dos seus direitos consuetudinários, os seus costumes e foros (séculos XIII). Partindo destes pressupostos, é possível também conhecer algumas profissôes (mesteres e agentes comerciais), locais de comércio, entre outros detalhes relacionados com desenvolvimento das atividades económicas urbanas.

Palavras-Chave: Portugal, Idade Média; costumes e foros; "delitos económicos”; Abastecimento.

\section{ABSTRACT}

The aim of this study is to provide an analysis about the conflicts and "economic crime", as well the social and penal laws mechanisms employed in the Portugueses town councils (Alfaiates, Castelo Bom, Castelo Melhor, Castelo Rodrigo, Guarda, Santarém, Torres Novas, Évora e Beja), to regulate the economic sectors, defending their populations and guaranteeing the supply of products and that are food necessary in the daily routine, through common-laws, custumary and laws ( $13^{\text {th }}$ Century). Leaving these assumptions is also posible to know any professions ("mesteirais" and commercial agents), commerce places, among other details related with development of urban economics activities.

Keywords: Portugal; Middle Ages; customs and law; economic crime; supply.

DOI - http://dx.doi.org/10.1590/2237-101X017033009

Artigo recebido em 20 de fevereiro de 2016 e aprovado para publicação em 10 de agosto de 2016.

* Professora no Instituto de Estudos Medievais da Universidade Nova de Lisboa. E-mail: alice.tavares@ gmail.com. 


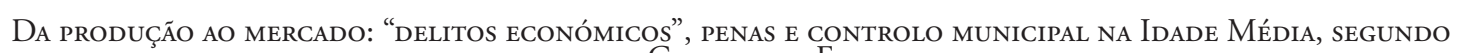
O TESTEMUNHO DOS COSTUMES E ForOS PORTUGUESES

Maria Alice da Silveira Tavares

Os "delitos económicos" e o abastecimento dos centros urbanos constituíram um problema para as autoridades municipais portuguesas, segundo os seus costumes e foros (século XIII). ${ }^{1}$ Através deles, podemos comprovar que nem sempre a produção de produtos e as trocas comerciais se desenrolavam nas melhores condiçôes, causando uma série de conflitos e de entraves que afetavam a circulação e o aprovisionamento de bens e de géneros alimentares às populaçôes, lesando particularmente os consumidores. Os concelhos intervieram assim no desenvolvimento dos setores da economia, regulando todas as etapas da produçáo até à colocação dos produtos no mercado.

As temáticas sobre a criminalidade económica na Idade Média não têm merecido especial atenção por parte da historiografia portuguesa. ${ }^{2}$ Em Espanha assistimos, porém, a um maior interesse sobre estas problemáticas, sobretudo numa perspetiva transdisciplinar, reunindo contributos nas áreas da história, do direito e da história económica. ${ }^{3}$ Esses estudos estão ainda relacionados com outras questóes importantes para compreender os delitos e os problemas que costumavam ocorrer no desenvolvimento do trabalho mesteiral e das transaçôes comerciais, essenciais para garantir o aprovisionamento das populaçóes medievas, tais como a organizaçáo dos espaços de comércio; os mecanismos de segurança e policiamento dos mesmos; a definição de preços, pesos e medidas e entre outras questôes.

\footnotetext{
${ }^{1}$ Os costumes e foros objeto de consideração encontram-se conservados no Arquivo Nacional da Torre do Tombo (IANTT), em Lisboa. Foram editados no século XIX por José Correia Serra, em 1824, e por Alexandre Herculano, em 1856. Os foros extensos de Santarém tiveram também uma outra edição, levada a cabo por Zeferino Brandão, em 1883.

2 São muito escassos os estudos sobre estes temas, sobretudo, a partir de fontes jurídicas, embora possamos encontrar alguns contributos. Veja-se, GONÇALVES, Iria. Defesa do consumidor na cidade medieval: os produtos alimentares (Lisboa - séculos XIV-XV). Arquipélago. Revista da Universidade dos Açores, Ponta Delgada, n. 1, p. 29-48, 1995. Disponível em: <https://repositorio.uac.pt/bitstream/10400.3/501/1/IriaGoncalves_p29-48.pdf>. Acesso em: 30 out. 2012.

${ }^{3}$ Por exemplo BONACHÍA HERNANDO, Juan Antonio. Abastecimiento urbano, mercado local y control municipal: la provisión y comercialización de la carne en Burgos (siglos XV). Espacio, Tiempo y Forma. Serie III. Historia Medieval, Madri, n. 5, p. 140-141, 1992. Disponível em: <http://e-spacio.uned.es/fez/eserv. php?pid=bibliuned:etffb773a7e-2555-6065-07f7-17991cc80854\&dsid=documento.pdf>. Acesso em: 6 abr. 2013; ESCRIBANO ABAD, José Luís. La regulación del mercado alimentario: el caso de la Guadalajara bajomedieval. Espacio, Tiempo y Forma. Serie III. Historia Medieval, Madri, n. 21, p. 109-137, 2008. Disponível em: <http://e-spacio.uned.es/fez/eserv.php?pid=bibliuned:etfserieiii2008n21-10510\&dsid=documento. pdf $>$. Acesso em: 21 jul. 2001; JARA FUENTE, José Antonio. Élites urbanas: las políticas comerciales y de mercado como formas de prevención de conflictos y de legitimación del poder (la veda del vino en Cuenca en la Baja Edad Media). Brocar: cuadernos de investigación histórica, Logroño, n. 21, p. 119-133, 1998. Disponível em: <http://dialnet.unirioja.es/servlet/articulo?codigo=227748>. Acesso em: 30 dez. 2012; TORQUEMADA, María Jesús. Algunos aspectos de la regulación sobre consumo en la Baja Edad Media castellana: pesas y medidas, ocupación de locales y horarios de comercio. Revista de la Facultad de Derecho de la Universidad Complutense, Madri, n. 84, p. 447-468, 1992-1994.
} 


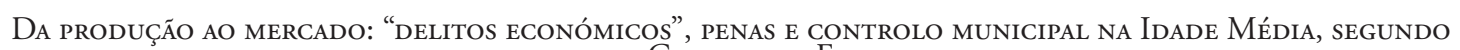
O TESTEMUNHO DOS COSTUMES E Foros PORTUGUESES

Neste sentido, o presente texto tem assim como objetivo analisar os "delitos económicos", os conflitos, bem como as medidas preventivas e de controlo social, a par da fixação de um sistema de penalizaçóes que visavam punir todos aqueles que cometessem fraudes e outras transgressões, minimizando os problemas na adquisição de bens e produtos nos núcleos urbanos, a partir de uma única fonte de caráter jurídico: os costumes e foros. A par destas reflexôes que pretendemos fazer, daremos a conhecer ainda algumas profissóes (mesteres e agentes comerciais), os locais de comércio, entre outros detalhes relacionados com o desenvolvimento das atividades económicas urbanas.

Neste estudo serão portanto utilizados os regulamentos locais de caráter consuetudinário que chegaram até aos dias de hoje. São assim objeto de análise os costumes e foros da região de Riba-Côa (Alfaiates, Castelo Bom, Castelo Melhor e Castelo Rodrigo), atuais povoados portugueses, após a celebração do Tratado de Alcanices, em 1297, que marcou uma etapa da definição da fronteira luso-castelhana, ao passo que as vilas Cáceres, Coria, Usagre e Salvaleón permaneceram no Reino de Castela e Leão, localizadas atualmente na Região Autónoma da Extremadura. Excetua-se, porém, Salvaleón, uma vez que esta vila desapareceu, com Carlos V (1500-1558), imperador do Sacro Império Romano-germânico. Complementamos ainda a nossa análise com os costumes e foros das cidades da Guarda, Santarém, Torres Novas, Beja e Évora, com o fim de enriquecermos o nosso estudo, possibilitando-nos um cotejo mais minucioso entre fontes da mesma natureza. Não obstante, esta última cidade é um caso particular, porque as suas normativas encontram-se atualmente desaparecidas. Sendo assim, recorreremos aos códigos municipais dos povoados de Terena, Alcáçovas e Garvão, situados no Alentejo, visto que receberam os direitos locais eborenses, adaptando-os e modificando-os, segundo as necessidades das suas populaçôes. ${ }^{4}$ Deste modo, conseguimos fazer uma aproximação ao corpo costumeiro de Évora, através das localidades recetoras do direito municipal eborense, embora para este estudo utilizemos como instrumento de trabalho os preceitos de Terena, pelo facto de neles se encontrarem registadas normas sobre os delitos "económicos".

Estão assim lançados os pontos de partida que nos acompanharão ao longo deste estudo. Antes de avançarmos para uma análise mais minuciosa dos delitos e dos conflitos que costumavam ocorrer durante os processos de produção e comercialização, convém chamar a atenção para um aspeto concetual, que estará presente ao longo deste trabalho e que será o ponto basilar deste texto, lançando a seguinte questáo: o que se entende por "delitos económicos"? Sáo todas as atividades delituosas contra a economia, ${ }^{5}$ entre as quais podemos encontrar as infraçôes contra a qualidade e a composição dos bens e gêneros alimentares,

\footnotetext{
${ }^{4}$ CINTRA, Luís Filipe Lindley Cintra. A linguagem dos Foros de Castelo Rodrigo, e seu confronto com a dos Foros de Alfaiates, Castelo Bom, castelo Melhor, Coria, Cáceres e Usagre. Contribuição para o estudo do leonês e do galego - português do século XIII. Lisboa: INCM, 1984, p. XCI.

${ }^{5}$ Delitos antieconómicos. Ed. Polícia de Segurança Pública - Escola Prática. Torres Novas: Escola Prática, 2004, p. 3 .
} 


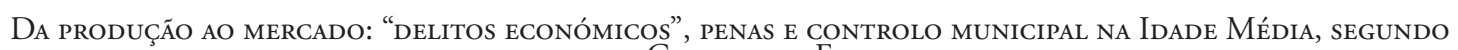
O TESTEMUNHO DOS COSTUMES E Foros PORTUGUESES

Maria Alice da Silveira Tavares

colocando em "causa os valores da vida, da saúde e da integridade física"; 6 o crime de açambarcamento, a especulação etc. Apesar de estarmos diante de um conceito contemporâneo e anacrónico, as fontes selecionadas deixam já transparecer uma clara consciência das populações medievas em regulamentar, prevenir e combater as transgressôes e os crimes contra as atividades económicas e o seu devido funcionamento, zelando pelo correto ordenamento socioeconómico dos concelhos, como iremos verificar mais adiante, atendendo aos regulamentos costumeiros.

Dividiremos, portanto, o nosso estudo em três tópicos diferentes. Em primeiro lugar, daremos a conhecer os costumes e foros de forma mais alargada e pormenorizada, esclarecendo a importância e as potencialidades dessas fontes para o estudo da criminalidade, nas suas mais variantes, como, por exemplo, a económica, em destaque no presente artigo. Pretendemos assim com este apartado fazer uma apresentação desta fonte, uma vez nos iremos centrar exclusivamente sobre ela para examinarmos em detalhe os "delitos económicos" e as formas de penalização e controlo municipal. Em segundo lugar, procederemos à apresentação e à análise dos delitos e conflitos que pudessem advir do mau funcionamento das atividades económicas, com o fim de prejudicar o abastecimento das populaçôes e enganar os consumidores. Por último, consideraremos o estudo das soluçóes, das molduras penais e dos instrumentos de controlo social, para minimizar os impactos e as consequências dos referidos problemas, que podemos depreender através da leitura e interpretação dos ordenamentos costumeiros.

\section{Costumes e foros: definição e potencialidades}

Como já referimos anteriormente, os costumes e foros são regulamentos municipais de natureza consuetudinária, que foram passados a escrito a partir dos finais do século XII até aos inícios do século XIV, uma vez que estamos diante de normativas transmitidas oralmente, de geração em geraçáo. Foi, desta maneira, que se formaram as compilaçôes de ordenamentos costumeiros, designadas de códigos. ${ }^{7}$ Este processo decorreu de forma paulatina da parte das próprias comunidades em redigir os seus direitos consuetudinários, apesar de ser difícil definir uma data para os situar no tempo.

Os problemas de datação que advêm dessas fontes devem-se ao facto de termos acesso a escassas mençóes cronológicas, como podemos constatar, por exemplo, nos costumes e foros de Santarém, Torres Novas, Évora e Guarda, que deverão corresponder ao momento de fixaçáo das normas locais por escrito. Como acabamos de verificar, o acto de redigir os

\footnotetext{
${ }^{6}$ Ibidem, p. 4.

${ }^{7}$ Luís Filipe Lindley Cintra, A linguagem dos Foros de Castelo Rodrigo, e seu confronto com a dos Foros de Alfaiates, Castelo Bom, castelo Melhor, Coria, Cáceres e Usagre. Contribuição para o estudo do leonês e do galego — português do século XIII, op. cit., p. XCI.
} 


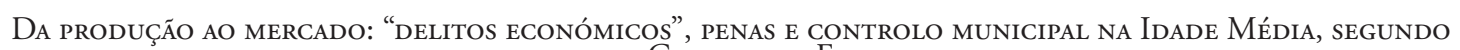
O TESTEMUNHO DOS COSTUMES E Foros PORTUGUeSES

Costumes e Foros de um município terá sido um procedimento parcimonioso, compreendendo um vasto período de tempo, de mais de um século. Quer isto dizer, que a redacção dos estatutos municipais se manifestava, possivelmente, muito antes dos fins do século XII, desde o reinado de d. Sancho I (1185-1211) até ao soberano, d. Dinis (1279-1325). As datas que se podem encontrar nas fontes remetem-nos principalmente para o reinado dionisiano. No código costumeiro da Guarda encontramos contudo um outro tipo de indicação que faz alusão ao monarca d. Sancho I (1185-1211), à sua mulher e aos seus filhos, ${ }^{8}$ o que nos sugere que o início do trabalho da passagem a escrito dos costumes e foros era anterior, remontando-nos aos fins do século XII e princípios do século XIII.

A par das referências cronológicas e onomásticas, consideramos também os topónimos como indicadores importantes para datar a redação das normas costumeiras, levando-nos a colocar em cima da mesa outras hipóteses. É o que sucede com o topónimo de uma localidade situada a norte do país: "Guimarães", que se encontra nos costumes e foros de Santarém.? A referência a este concelho levanta-nos o problema da antiguidade das normativas. Ou seja, a sobrevivência residual deste topónimo permite-nos inferir que estamos diante de um foro muito antigo provavelmente anterior ou proveniente do período Condal (séculos XI-XII), pois Guimarães era Sede Condal.

Não obstante, os costumes e foros de Riba-Côa têm uma cronologia diferente, correspondendo aos reinados dos reis do Reino de Leâo (d. Afonso IX e d. Fernando III). Esses corpora costumeiros foram concedidos por iniciativa régia, com o objetivo de impulsionar e desenvolver o povoamento de espaços pouco apelativos e carentes de efetivos populacionais, num contexto de reconquista e de definição de fronteiras com o reino português.

Essas normativas costumeiras podiam ser comunicadas a outras localidades, parcialmente ou na íntegra, dando lugar a famílias de "Foros extensos, idênticos ou muito parecidos em grande parte da sua extensão, mais diversos em pormenores de maior ou menor relevância". ${ }^{10}$ A família dos costumes e foros de Santarém é um dos exemplos ao comunicar as suas normativas às vilas alentejanas de Borba, Oriola e Vila Nova do Alvito (atual Baronia). Há, no entanto, casos em que algumas comunidades receberam os seus códigos costumeiros por iniciativa régia, no momento da sua fundaçáo, no momento de Reconquista, tais como os concelhos de Riba-Côa.

Outra forma de divulgação dos corpora costumeiros consistiu nos pedidos levados a cabo pelas populaçóes recetoras. Ou seja, umas vilas demonstraram preferência e interesse pelos

${ }^{8}$ CFB, PMH - LG. Olisipone: IUSSU Academiae Seicentiarum Olisiponensis, MDCCCLVI. v. II, p. 7, Tít. [61].

${ }^{9}$ CFB, PMH - LG. Olisipone: IUSSU Academiae Seicentiarum Olisiponensis, MDCCCLVI, v. II, p.18, Tít. [1]; BRANDÃO, Zeferino. Monumentos e lendas de Santarém. Lisboa: David Corazzi - Editor, 1883, p. 360-361, Tít. [1].

${ }^{10}$ CINTRA, Luís Filipe Lindley. A linguagem dos Foros de Castelo Rodrigo, e seu confronto com a dos Foros de Alfaiates, Castelo Bom, castelo Melhor, Coria, Cáceres e Usagre. Contribuição para o estudo do leonês e do galego — português do século XIII, op. cit., p. XCI. 


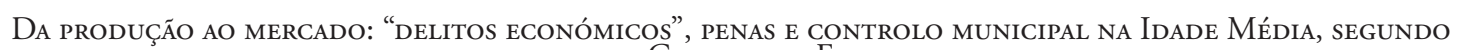
O TESTEMUNHO DOS COSTUMES E Foros PORTUGUeSES

costumes e foros de outras localidades, pedindo-lhes que lhos comunicassem. A passagem a escrito e o fenómeno da comunicação dos costumes e foros a outras localidades estavam relacionados com a afirmação e a intervenção do poder régio, que começou a fazer-se notar já com d. Dinis, na organização do reino, em detrimento da legislação consuetudinária. ${ }^{11}$ Procedeu-se, deste modo, à tentativa de formação de famílias de costumes e foros.

A eleição desses códigos costumeiros deve-se à importância dessas fontes para o conhecimento dos quotidianos e da vida social, jurídico-económica e administrativa dos concelhos, uma vez que funcionavam como uma espécie de espelho dos comportamentos das suas gentes e, por outro lado, oferecem-nos vastíssimas informações, múltiplos campos de estudo e possibilidades de compreender as esferas das sociedades nos núcleos urbanos portugueses de áreas geográficas diferentes. Além disso, há a vantagem excecional de poder conhecer como se organizavam as atividades económicas; os crimes e os conflitos que daí recorriam; as reaçóes e as soluçóes encontradas pelos concelhos objeto de estudo para fazer face a essas situaçôes, que podiam trazer como consequências problemas de abastecimento nas trocas comerciais e também disputas no seio das populações. Após esta apresentação sobre as fontes jurídicas em consideraçáo e as suas potencialidades, vejamos, então, de seguida com mais detalhe os tipos de "delitos económicos" e como eram levados a cabo.

\section{Da produção ao comércio: conflitos e "delitos económicos"}

Nas cidades e vilas medievas costumava-se praticar uma série de delitos e transgressôes contra o bom funcionamento da economia, comprometendo o abastecimento e o consumo urbanos, como enunciamos anteriormente. Nos 2.859 costumes e foros estudados ${ }^{12}$ podemos encontrar 58 normativas sobre "delitos económicos", representando 2\%. Neste grupo de normas costumeiras conseguimos detetar os crimes de fraude, com 58,6\%; o açambarcamento (13,7\%); a especulaçáo $(5,17 \%)$ e a presença de outras transgressôes $(22,4 \%)$, tais como a alteração de preços, a manipulação dos pesos e das medidas. É através dessas fontes locais que temos conhecimento de que se produziam e se fabricavam produtos com defeitos e impróprios para consumo; vendiam-se mercadorias com problemas como se fossem de boa qualidade, açambarcavam-se bens e géneros alimentares; especulavam-se e inflacionavam-se os preços, adulteravam-se os pesos e as medidas. A par dos exemplos acabados de enumerar, a circulação e a distribuição de bens e mercadorias eram também afetadas. Essas práticas estavam ainda associadas à monopolização dos produtos, com o fim de serem adquiridos

\footnotetext{
${ }^{11}$ SILVA, Nuno Gomes Espinosa da. História do Direito Português. Lisboa: Edição da Associação Académica da Faculdade de Direito, 1971, p. 303-304.

${ }^{12}$ Consideramos os costumes e foros dos núcleos urbanos, onde é possível encontrar normas sobre delitos económicos: Alfaiates, Beja, Borba, Castelo Bom, Castelo Melhor, Castelo Rodrigo, Santarém, Terena (Évora) e Torres Novas.
} 


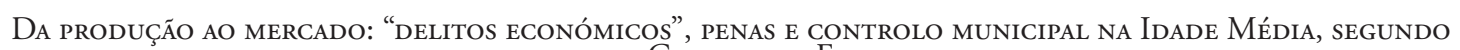
O TESTEMUNHO DOS COSTUMES E Foros PORTUGUeSES

Maria Alice da Silveira Tavares

em quantidades superiores às necessidades de abastecimento normal, condicionando assim o acesso e a venda dos mesmos.

Diante desta série de problemas, comecemos com a análise da fraude, que constituía um problema para as autoridades municipais. Apesar de se tratar de um crime contra o património em geral, pois atentava contra os bens próprios, não deixava de afetar as atividades económicas. Partia, sobretudo, de um ardil e da capacidade para tirar proveito das necessidades, fragilidades ou dos benefícios dos outros, com o objetivo de satisfazer interesses gananciosos, procurando, acima de tudo, o enriquecimento fácil e ilegítimo. As burlas eram frequentes entre os mesteirais e os comerciantes, sem esquecer, os regateiros que tinham o hábito de enganar os consumidores, como, por exemplo, ao fabricar e adulterar os seus produtos (bens alimentares, materiais de construção, têxteis, etc.) e de os comercializar a preços geralmente elevados como se fossem mercadorias de qualidade, fazendo-as passar por autênticas e aptas para o consumo das populaçóes. ${ }^{13} \mathrm{Ou}$ seja, enganava-se e prejudicava-se os consumidores, aportando-lhes prejuízos patrimoniais, visto que adquiriam os produtos sem estar nas melhores condiçôes. As pessoas não eram portanto as únicas a saírem lesadas, como acabamos de ver. Essas condutas visavam também uma "instituición o sus decisiones, com dudables matices económicos", ${ }^{14}$ constituindo um problema para os próprios municípios. Deste modo, recaía, sobretudo, nos concelhos o controlo das atividades económicas, através de um conjunto de normativas sobre as caraterísticas das matérias-primas, dos produtos e a fixação dos preços, das medidas e dos pesos usados nos concelhos, com o intuito de garantir o bom funcionamento das atividades industriais, mercantis e o abastecimento das populaçóes. Pretendia-se assim assegurar a produção de bens de qualidade, sem defeitos e próprios para consumo, e controlar as transaçōes comerciais, através do estabelecimento de uma espécie de "tabelas" de preços e de normas fiscais patentes nos costumes e foros, onde são descritos os tributos que recaíam sobre bens e pessoas.

Como acabamos de constatar, a indústria e o comércio eram portanto os setores mais propensos a transgressóes e a comportamentos delituosos, merecendo especial atençáo da parte das autoridades municipais. Vejamos, com mais detalhe, os seguintes exemplos em função da área profissional, começando por salientar as práticas das padeiras. Estas costu-

\footnotetext{
${ }^{13}$ Sobre as burlas levadas a cabo pelas padeiras: CFA, $P M H-L G$. Olisipone: IUSSU Academiae Seicentiarum Olisiponensis, MDCCCLVI, v. I, p. 808, Tít. [157]; CFCB, PMH - LG. Olisipone: IUSSU Academiae Seicentiarum Olisiponensis, MDCCCLVI, v. I, p. 763, Tít. [157]. Veja-se: GONÇALVES, Iria. Defesa do consumidor na cidade medieval: os produtos alimentares (Lisboa - séculos XIV-XV). Arquipélago. Revista da Universidade dos Açores, op. cit., p. 29-48, 1995.

Sobre as burlas praticadas pelos sapateiros: CFCB, $P M H-L G$, op. cit., p. 768, Tít. [201]; CFCM, $P M H$ — LG. Olisipone: IUSSU Academiae Seicentiarum Olisiponensis, MDCCCLVI, v. I, p. 927 Tít. [263], Lv. VI; CFCR, PMH - LG. Olisipone: IUSSU Academiae Seicentiarum Olisiponensis, MDCCCLVI, v. I, p. 882, Tít. [276], Lv. VI.

${ }^{14}$ BERNAL PENAA, José. Golfines y asesinos. Elementos y motivaciones de las conductas violentas en Murcia durante el siglo XIV. MVRGETANA, Murcia, n. 125, p. 75, 2011. Disponível em: <http:/dialnet.unirioja.es/ servlet/articulo?codigo=3768237>. Acesso em: 9 mar. 2013.
} 


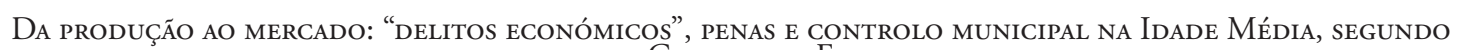
O TESTEMUNHO DOS COSTUMES E Foros PORTUGUESES

Maria Alice da Silveira Tavares

mavam vender pão mal cozido, impróprio para consumo. Diante dessas circunstâncias, os compradores de Riba-Côa eram obrigados a devolver os pães previamente cortados para ser testada a qualidade, ficando as padeiras obrigadas a recebê-los de volta e, além disso, deviam ser multadas. ${ }^{15}$

Os ferradores ribacoanos eram outro caso semelhante, pois nem sempre fabricavam ferraduras em condiçôes que durassem muito tempo colocadas nos cascos dos animais. Havia casos em que se partiam ou caíam antes de findar o prazo da "garantia" de nove dias, ficando os ferradores obrigados a reparar os estragos gratuitamente. A isto acrescia o problema de os ferreiros fabricarem também ferraduras, gerando alguma controvérsia e disputas entre ambos os grupos profissionais. Os ferradores não deixavam, porém, de alegar que as ferraduras realizadas pelos ferreiros costumavam ter defeitos de fabrico e, além disso, eram feitas com pregos de má qualidade. ${ }^{16}$ Com base nessas razóes apresentadas nas normativas, podemos inferir uma situação de rivalidade e uma incompatibilidade nítida de interesses entre ambas as profissóes, pois tinham em comum o trabalho da mesma matéria-prima: o ferro. Por outro lado, podemos evidenciar uma clara especialização profissional, dando lugar ao aparecimento de novos ofícios, que se manifestava desde os finais do século XII.

O mesmo se pode dizer do setor da construçáo civil. Os telheiros eram outros profissionais que não costumavam ter em atenção à qualidade dos seus produtos, uma vez que era comum as telhas e os tijolos se deteriorarem com a água, antes de um prazo de um ano, colocando em risco as construções. ${ }^{17}$

Esses casos ilustram claramente que as atividades mesteirais e os seus profissionais se encontravam devidamente regulamentados nos costumes e foros, chegando ao ponto de existirem normativas específicas para cada setor industrial, desde o têxtil, a alimentação, a metalurgia, a construção civil e outros. A essas atividades estavam ligadas um sem-fim de profissôes, tais como os ferreiros, os ferradores, os ourives, os caleiros, os carpinteiros, as padeiras, os carniceiros, as taberneiras, os peleiros, os curtidores, os tecedores, as fiandeiras, os cardadores, as sapateiros, os alfaiates e os oleiros. Ou seja, cada mesteiral ganhava uma "entidad, reconociéndosele un valor y utilidad para la comunidad". ${ }^{18}$ Todos eles de-

${ }^{15}$ CFCB, $P M H-L G$, op. cit., p. 763, Tít. [157]; CFCM, PMH - LG, op. cit., p. 925, Tít. [249], Lv. VI; CFCR, $P M H-L G$, op. cit., p. 881, Tít. [262], Lv. VI; CFA, $P M H-L G$, op. cit., p. 808, Tít. [157]. Veja-se, MARTÍNEZ MARTÍNEZ, Julio Gerardo. Los oficios menestrales en los Fueros de Cáceres. Anuario de la Facultad de Derecho, Cáceres, n. 3, p. 162, 1984-1985.

${ }^{16}$ CFCB, $P M H-L G$, op. cit., p. 757, Tít. [107]; CFCM, $P M H-L G$, op. cit., p. 925, Tít. [246], Lv. VI; CFCR, $P M H-L G$, op. cit., p. 881, Tít. [259], Lv. VI; CFA, $P M H-L G$, op. cit., p. 803, Tít. [112]. Sobre o assunto leia-se MARTÍNEZ MARTÍNEZ, Julio Gerardo. Los oficios menestrales en los Fueros de Cáceres. Anuario de la Facultad de Derecho, op. cit., p. 162.

${ }^{17}$ CFCB, $P M H-L G$, op. cit., p. 757, p. 786, Tít. [377]; CFCM, $P M H-L G$, op. cit., p. 926-927, Tít. [261], Lv. VI; CFCR, $P M H-L G$, op. cit., p. 882, Tít. [274], Lv. VI; CFA, $P M H-L G$, op. cit., p. 833, Tít. [390].

${ }^{18}$ GONZÁLEZ ARCE, José Damián. El artesanado en los Fueros del Reino de Murcia. Anuario de Estudios Medievales, Madri, n. 25, p. 88, 1995. 


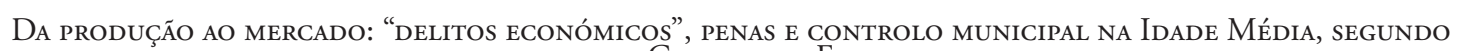
O TESTEMUNHO DOS COSTUMES E FOROS PORTUGUESES

Maria Alice da Silveira Tavares

viam obedecer aos "coutos", isto é, os padróes "industriais" e "comerciais" municipais, com o objetivo de controlar principalmente a produçáo, o comércio e o abastecimento das populaçôes, proporcionando-lhes produtos de boa qualidade, em função dos preços estabelecidos previamente.

O setor do comércio era também problemático e alvo de conflitos, como deixam transparecer os corpora costumeiros, apesar de, em teoria, as mercadorias deverem ser colocadas à venda em boas condiçôes e sem defeitos de fabrico. Era vulgar os mesteirais e os comerciantes colocarem à disposição das pessoas produtos em más condiçôes, geralmente a preços elevados como se tratassem de mercadorias sem defeitos. Os carniceiros constituíam um dos exemplos. Estes tinham o costume de comercializar carne fedorenta, inchada, em estado de decomposição, imprópria para consumo juntamente com as frescas, colocando em risco a saúde e a higiene pública. Vendiam um pouco de tudo, desde carneiros, ovelhas, cordeiros, cabritos, coelhos, lebres e aves de caça. Os preços das carnes estavam devidamente tabelados pelos concelhos, se bem que nem sempre seriam seguidos à risca, embora não seja propósito deter-nos com detalhe neste tipo de questóes. ${ }^{19}$ Já os carniceiros judeus de Castelo Melhor foram também alvo de restrições, pois estavam proibidos de vender carne na carniçaria, apesar de ser comum receberem clientes cristáos. ${ }^{20}$ Esta proibiçáo depreende-se com questôes de natureza religiosa, uma vez que o manuseamento de determinados alimentos, tais como a carne, o peixe e o vinho, dependia da prática certos rituais, segundo os seus preceitos religiosos, que estavam relacionados com a noção de pureza de ambas as religióes.

O comércio do vinho era outro problema para os concelhos. Era normal apregoar a venda deste produto, com "publicidade enganosa", enganando os clientes com o uso de medidas

19 CFCB, $P M H-L G$, op. cit., p. 789, Tít. [397]; CFCM, PMH - LG, op. cit., p. 925, Tít. [244], Lv. VI; CFCR, $P M H-L G$, op. cit., p. 880, Tít. [257], Lv. VI. Sobre os preços das carnes, não se encontra nenhuma normativa sobre esta temática nos costumes e foros de Castelo Melhor, Alfaiates e Castelo Rodrigo. Veja-se: GOICOLEA JULIÁN, Fco Javier. Mundo urbano y actividades económicas en la Rioja Alta bajomedieval. Espacio, Tiempo y Forma. Serie III. Historia Medieval, Madri, n. 11, p. 272-273, 1998. Disponível em: <http://e-spacio.uned.es/fez/eserv.php?pid=bibliuned:ETF61C966A9=-2DDF-D0FB18-EE-0ADF24E1D0DA\&dsIDDocumento.pdf $>$. Acesso em: 12 dez. 2012; HINOJOSA MONTALVO, José. Poder municipal y abastecimiento de carne en la gobernación de Orihuela a fines de la Edad Media. Miscelánea Medieval Murciana, Murcia, n. 21-22, p. 161-162, 1997-1998. Disponível em: <http://dialnet.unirioja.es/servlet/articulo?codigo=52955>. Acesso em: 30 dez. 2012; AGUADÉ NIETO, Santiago: CABAÑAS, María Dolores. Comercialización y sociedad urbana en la Castilla medieval. La comercialización de la carne en Cuenca (1177-1500). Anuario de Estudios Medievales, Madri, n. 14, p. 490-491, 1984; BUENO DOMÍNGUEZ, María Luisa. Contactos con la vida material en Zamora. Siglos XII-XV. Espacio, Tiempo y Forma. Seria II, Historia Medieval, Madri, n. 18, p. 52, 2005. Disponível em: <http://e-spacio.uned.es/fez/eserv.php?pid=bibliuned:ETF43772BD6-0E92-A2F8-7C0B-FAED390306EA\&dsID=Documento.pdf>. Acesso em: 9 set. 2011.

${ }^{20}$ CFCR, PMH - LG, op. cit., p. 882, Tít. [270], Lv. VI; CFCM, PMH - LG, op. cit., p. 926, Tít, [257], Lv. VI. Sobre este tema, leia-se CANTERA MONTENEGRO, Enrique. La carne y el pescado en el sistema alimentario judío en la España Medieval. Espacio, Tiempo y Forma. Serie III. Historia Medieval, Madri, n. 16, p. 42-43, 2003. Disponível em: <http://e-spacio.uned.es/fez/eserv.php?pid=bibliuned:ETF366B37E9-B682-D954-BEFD-7F1F77C2556E\&dsID=PDF>. Acesso em: 12 fev. 2011. 
DA PROdUÇÃo AO MERCADO: "DELITOS ECONÓMICOS", PENAS E CONTROlO MUNICIPAL NA IDADE MÉdia, SEGUNDO O TESTEMUNHO DOS COSTUMES E FOROS PORTUGUESES

Maria Alice da Silveira Tavares

falsas, como acontecia em Alfaiates. ${ }^{21}$ Também nem sempre se colocava à venda vinho de boa qualidade. Este era facilmente adulterado, visto que havia o costume de misturar vinho bom com outro de má qualidade, falsificando-o em prejuízo dos consumidores, como elucidam os costumes e foros. As vilas de Alfaiates, Santarém e Évora não foram negligentes a este tipo de situaçôes, sancionando os infratores. ${ }^{22} \mathrm{Já}$ em Évora, se apostou em medidas preventivas que estavam a cargo dos almotacés. Estes deviam assim ter o cuidado de experimentar o vinho proveniente de fora, retirando uma amostra, através de uma infusa (espécie de bilha), com a finalidade de ser testada a qualidade e a composição do produto. Ou seja, a ideia consistia em averiguar se o vinho tinha sido manipulado ou não, sofrendo alguma mistura de outros líquidos, tais como a água. ${ }^{23}$ Assim acontecia também em Torres Novas $^{24}$ e em Beja. ${ }^{25}$ As taberneiras do concelho de Castelo Bom tinham o hábito de usar medidas incorretas ou falsas na venda do vinho. Dito isto de outra forma, estas nem sempre vendiam o vinho em função da quantidade solicitada pelos clientes e dos preços estabelecidos nos "marcos" dos concelhos, demonstrando que os esforços das autoridades municipais não costumavam surtir efeito. Neste sentido e, a modo de exemplo, o meio quarto de vinho devia custar seis dinheiros, segundo o estipulado nos costumes e foros de Castelo Bom. ${ }^{26}$

Atendamos ao que acontecia na área da construçâo civil com o caso dos carpinteiros de Riba-Côa, constituindo mais um exemplo semelhante aos demais mesteres, visto que tinham o hábito de venderem tábuas e madeiras com nós e outras imperfeiçóes. ${ }^{27}$

As vendas fraudulentas não se ficavam por aqui. Esses comportamentos não só eram levados a cabo pelos mesteirais, abrangendo também outras profissóes ligadas exclusivamente ao comércio. Os regateiros constituíam uma realidade particular, visto que se dedicavam unicamente ao comércio a retalho de vários produtos, tais como pão, aves, peixe, lenha, frutas e legumes ${ }^{28}$ funcionando como intermediários. Esses revendedores estavam mal vistos porque

${ }^{21}$ CFA, PMH - LG, op. cit., p. 836, Tít. [417]. Esta vila foi ainda mais longe ao censurar todos os pregóes falsos no mercado e nos alfozes. Coteje-se, CFA, $P M H-L G$, op. cit., p. 840, Tít. [470].

${ }^{22}$ CFA, PMH - LG, op. cit., p. 839, Tít. [839]. Veja-se, VIANA, Mário. Os vinhedos medievais de Santarém. Cascais: Patrimonia Histórica, 1998, p.184.

${ }^{23}$ CTCE, PMH - LG. Olisipone: IUSSU Academiae Seicentiarum Olisiponensis, MDCCCLVI. v. II, p. 84, Tít. [29]. Veja-se GONÇALVES, Iria. Defesa do consumidor na cidade medieval: os produtos alimentares (Lisboa - séculos XIV-XV). Arquipélago. Revista da Universidade dos Açores, op. cit., p. 45; VIANA, Mário. Os vinhedos medievais de Santarém, op. cit., p. 184.

${ }^{24}$ CFTN, PMH - LG. Olisipone: IUSSU Academiae Seicentiarum Olisiponensis, MDCCCLVI. v. II, p. 92, Tít. [52].

${ }^{25}$ CFB, $P M H-L G$, op. cit., p. 68, Tít. [197].

${ }^{26}$ CFCB, PMH - LG, op., cit., p. 789, Tít. [398]. Leia-se TORQUEMADA, María Jesús. Algunos aspectos de la regulación sobre consumo en la Baja Edad Media castellana: pesas y medidas, ocupación de locales y horarios de comercio. Revista de la Facultad de Derecho de la Universidad Complutense, op. cit., p. 447-468. ${ }^{27}$ CFCB, $P M H-L G$, op. cit., p. 760, Tít. [129]; CFCM, $P M H-L G$, op. cit., p. 927, Tít. [262], Lv. VI; CFCR, $P M H-L G$, op. cit., p. 882, Tít. [275], Lv. VI; CFA, $P M H-L G$, op. cit., p. 805, Tít. [126].

${ }^{28}$ CFCB, $P M H-L G$, op. cit., p. 758, Tít. [110]; CFCM, $P M H-L G$, op. cit., p. 924, Tít. [235], Lv. VI; CFCR, $P M H-L G$, op. cit., p. 879, Tít. [248], Lv. VI; CFA, $P M H-L G$, op. cit., p. 803, Tít. [114]; CFB, PMH $-L G$, op. cit., p. 59, Tít. [72]. 


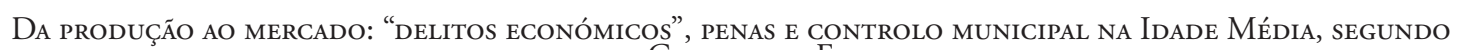
O TESTEMUNHO DOS COSTUMES E FOROS PORTUGUESES

Maria Alice da Silveira Tavares

tinham o hábito de enganar os consumidores nos seus negócios e a tendência a monopolizar as mercadorias para depois as venderem a preços mais elevados, ao mesmo tempo que prejudicavam o abastecimento normal, lesando as populaçóes no acesso ao consumo. ${ }^{29}$ Assim acontecia na vila de Santarém, a propósito do comércio do pão levado a cabo pelas regateiras. Estas tinham o hábito de comprar pães às padeiras para o revenderem, especulando o preço deste produto, consoante a demanda. ${ }^{30}$ Esta situação era análoga em Riba-Côa, em relação ao peixe. As autoridades locais desta região não fizeram vista grossa a este tipo de negócios, punindo duplamente os regateiros e a todos aqueles que lhes fornecessem peixe. ${ }^{31}$

O consumo de peixe nas festividades religiosas era alvo de conflitos nas vilas ribacoanas. Tratava-se de um alimento solicitado quer por cristáos nos dias de jejum, quer por judeus para a celebração do "Shabat", que se iniciava ao fim do dia de Sexta-feira e terminava no fim do dia de Sábado. Os regateiros, os vendedores e os judeus aproveitavam essas oportunidades para comprar, açambarcar e revender os peixes, contribuindo para o seu encarecimento. ${ }^{32}$ Diante deste cenário, levanta-se novamente a questão sociorreligiosa relacionada com o contato e a manipulação dos alimentos por pessoas judias ou cristâs, acrescentando mais uma outra interpretação para este tipo de fenómenos. Os concelhos demonstraram portanto a preocupação em estabelecer normas que restringissem as relaçóes comerciais e sociais entre ambos os grupos, que nem sempre seriam eficazes. Daí serem vedadas as vendas de peixe levadas a cabo por judeus.

O consumo de outros produtos, como as hortaliças, costumava ser motivo de problemas, sobretudo em determinadas épocas do ano, também correspondentes a festividades litúrgicas, como a Quaresma. Durante este período, as autoridades locais de Beja deviam redobrar os cuidados com as vendas efetuadas pelas regateiras, sujeitando-as a uma tributação especial de dois dinheiros para o açougueiro. ${ }^{33}$

Os intermediários eram portanto malvistos nos concelhos de Riba-Côa, Santarém, Évora e Beja. Estes eram encarados como agentes especuladores e responsáveis pela subida dos

\footnotetext{
${ }^{29}$ GONÇALVES, Iria. Defesa do consumidor na cidade medieval: os produtos alimentares (Lisboa — séculos XIV-XV). Arquipélago. Revista da Universidade dos Açores, op. cit., p. 34.

${ }^{30}$ BRANDÁO, Zeferino. Monumentos e lendas de Santarém, op. cit., p. 407-408, Tít. [228].

${ }^{31}$ CFCB, $P M H-L G$, op. cit., p. 772, Tít. [236]; CFCM, PMH - LG, op. cit., p. 921, Tít. [237], Lv. VI; CFCR, PMH - LG, op. cit., p. 880, Tít. [250], Lv. VI. Veja-se: LÓPEZ VILLALBA, José Miguel. Política local y abastecimiento urbano: el pescado en Guadalajara en la Baja Edad Media. Studia Historica. Historia Medieval, Salamanca, n. 25, p. 243.

${ }^{32}$ CFCM, PMH - LG, op. cit., p. 924, Tít. [239], Lv. VI; CFCR, PMH - LG, op. cit., p. 880, Tít. [252], Lv. VI. Veja-se: ESCRIBANO ABAD, José Luís. La regulación del mercado alimentario: el caso de la Guadalajara bajomedieval. Espacio, Tiempo y Forma. Serie III. Historia Medieval, op. cit., p. 109-137; GOICOLEA JULIÁN, Fco Javier. Mundo urbano y actividades económicas en la Rioja Alta bajomedieval. Espacio, Tiempo y Forma. Serie III. Historia Medieval, op. cit., p. 243-283; CANTERA MONTENEGRO, Enrique. La carne y el pescado en el sistema alimentario judío en la España Medieval. Espacio, Tiempo y Forma. Serie III. Historia Medieval, op. cit., p. 43.

${ }^{33} \mathrm{CFB}, P M H-L G$, op. cit., p. 59, Tít. [52].
} 


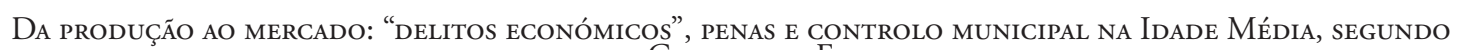
O TESTEMUNHO DOS COSTUMES E Foros PORTUGUESES

Maria Alice da Silveira Tavares

preços, manipulando as trocas comerciais para obterem lucros facilmente e de forma ilegítima, em prejuízo dos consumidores. Por todas essas razôes, esses comerciantes se encontravam sob constante vigilância. Na vila de Alfaiates, as regateiras eram sancionadas com o pagamento de uma coima e, se não tivessem capacidade económica para a pagar, eram "fustigadas" (castigadas fisicamente), ao passo que os homens eram presos no cepo durante dois meses. ${ }^{34}$ Por outro lado, os regateiros não deixavam de ter uma faceta importante como ser agentes reguladores do mercado, mantendo o equilíbrio entre a oferta e a procura. ${ }^{35}$

Os conflitos comerciais não só eram provocados pelos agentes intermediários, mas também por mercadores e almocreves. Estes tinham o hábito de medir mal, ${ }^{36}$ de usar medidas e pesos falsos e "estrangeiros", ${ }^{37}$ de outras localidades, com o intuito de enganar os clientes nas quantidades pretendidas. Aqueles que fossem apanhados em falso nas vilas ribacoanas pagavam uma multa aos "ochaveiros", funcionários municipais encarregados de regular e controlar os pesos e as medidas dos concelhos.

Alterar os preços estabelecidos pelos concelhos, sem qualquer pretexto e com a intenção de obter lucros ilegítimos, era uma prática decorrente, enganando os consumidores. Os agentes intermediários, como os regateiros, não eram os únicos a modificar os preços, contribuindo assim para a inflaçáo dos mesmos, ao açambarcarem as mercadorias para depois as revender. Contudo, atendemos nas normativas costumeiras uma outra forma de alterar os preçários afixados, levada a cabo pelos mesteirais, uma vez que tinham o hábito de exigir mais dinheiro pelos seus trabalhos, como sucedia com os sapateiros. Muitos deles cobravam mais de quatro morabitinos por colocar solas nos sapatos. ${ }^{38}$ Também era habitual alguns profissionais aproveitarem as solas gastas para as colocar nos sapatos, voltando-as ao contrário, como se fossem novas. Desta forma, lucravam e enganavam os clientes como se tivessem feito um arranjo, sem utilizar materiais novos. ${ }^{39}$

\footnotetext{
${ }^{34}$ CFA, PMH - LG, op. cit., p.828, Tít. [332].

${ }^{35}$ BONACHÍA HERNANDO, Juan Antonio. Abastecimiento urbano, mercado local y control municipal: la provisión y comercialización de la carne en Burgos (siglos XV). Espacio, Tiempo y Forma. Serie III. Historia Medieval, op. cit., p. 140-141.

${ }^{36}$ CFCB, $P M H-L G$, op. cit., p. 788, Tít. [396]; CFCM, $P M H-L G$, op. cit., p. 935-936, Tít. [343], Lv. VIII; CFCR, $P M H-L G$, op. cit., p. 892, Tít. [357], Lv. VIII.

${ }^{37}$ CFA, $P M H-L G$, op. cit., p. 824, Tít. [300].

${ }^{38}$ CFCB, $P M H-L G$, op. cit., p. 758, Tít. [113]; CFCM, $P M H-L G$, op. cit., p. 927, Tít. [264], Lv. VI; CRCR, PMH - LG, op. cit., p. 882, Tít. [277], Lv. VI; CFA, PMH - LG, op. cit., p. 804, Tít. [117]. Veja-se: MARTÍNEZ MARTÍNEZ, Julio Gerardo. Los oficios menestrales en los Fueros de Cáceres. Anuario de la Facultad de Derecho, op. cit., n. 3, p. 158.

${ }^{39}$ CFCB, $P M H-L G$, op. cit., p. 768, Tít. [201]; CFCM, PMH - LG, op. cit., p. 927, Tít. 263, Lv. VI; CFCR, PMH - LG, op. cit., p. 882, Tít. [276], Lv. VI. Veja-se, MENDO CARMONA, Concepción. La industria del cuero en la Villa y tierra de Madri a finales de la Edad Media. Espacio, Tiempo y Forma, Serie III. Historia Medieval, Madri, n. 3, p. 181-211, 1990. Disponível em: <http://e-spacio.uned.es/fez/eserv.php?pi$\mathrm{d}=$ bibliuned:ETF859480DA-15D9-2FDE-F0BE-F027B39BE50B\&dsID=Documento.pdf>. Acesso em: 30 dez. 2012.
} 


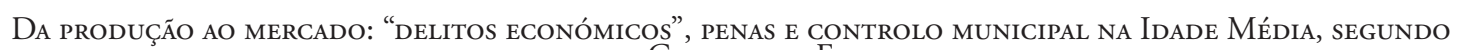
O TESTEMUNHO DOS COSTUMES E Foros PORTUGUeSES

\section{Da produção ao comércio: soluções, punições e medidas}

Como acabamos de constatar, abastecimento das populaçóes e o acesso ao consumo de bens acarretava uma série de problemas decorrentes de práticas delituosas que impediam o desenvolvimento normal das atividades económicas, provocando a escassez de víveres e de outros produtos. Diante desse panorama, como é que os concelhos procuraram fazer frente a essas situaçôes de conflito? Quais foram as suas soluçôes? São duas questôes que nos remontam para o papel intervencionista dos concelhos ao definirem assim um conjunto de normativas que visavam não só punir as infraçôes cometidas, mas também regular os "previsibles desajustes entre oferta, demanda y precio" ${ }^{40}$ como podemos depreender da leitura dos regulamentos costumeiros.

As autoridades locais apostaram principalmente no controlo dos setores, "industrial" e comercial, desde a produção até à colocação dos produtos no mercado. Estas definiram os "coutos" dos concelhos, isto é, regulamentos "industriais" e comerciais. Essas normas tinham como objetivo especificar as caraterísticas dos produtos; as matérias-primas e os ingredientes que deveriam ser utilizados; as medidas e os pesos; os preços do trabalho (mão de obra) dos mesteirais e os preços dos produtos finais no mercado. Também todos aqueles que infringissem as referidas normativas e burlassem os consumidores eram alvo de sançôes monetárias. Era o castigo mais comum, se bem que não costumasse ser aplicado de forma isolada, acarretando outras penalizaçóes, tais como a proibiçâo de os mesteirais exercerem as suas profissóes durante o ano em curso, lesando as suas atividades. Por outro lado, registamos ainda que os clientes tinham o direito de procurar outros mesteirais da concorrência para poderem fazer as suas encomendas, como sucedia nas vilas ribacoanas. ${ }^{41}$ As pessoas eram portanto incentivadas a reclamar e a denunciar estes casos quando se sentiam prejudicadas, pressionando os mesteirais. As populaçóes podiam, desta forma, ter acesso aos produtos com qualidade e em boas condiçóes para consumo.

Além disso, os mesteirais de Riba-Côa, tais como ourives, caleiros e ferreiros, eram obrigados a cumprir outros requisitos. Ter licença emitida pelos concelhos era fundamental para exercerem os seus ofícios, nos termos das vilas, embora nem sempre a solicitassem. ${ }^{42}$ Essas autorizaçóes deviam-se ao facto de se tratar de indústrias "poluentes" que podiam também ser perigosas para as populaçôes, trazendo-lhes riscos e incómodos. $\mathrm{O}$ desenvolvimento dessas manufaturas dependia dos fornos de transformação para funcio-

$\overline{40}$ BONACHÍA HERNANDO, Juan Antonio. Abastecimiento urbano, mercado local y control municipal: la provisión y comercialización de la carne en Burgos (siglos XV). Espacio, Tiempo y Forma. Serie III. Historia Medieval, op. cit., p. 88.

${ }^{41}$ CFCB, $P M H-L G$, op. cit., p. 763, Tít. [164]; CFCM, PMH - LG, op. cit., p. 926,Tít. [254], Lv. VI; CFCR, $P M H-L G$, op. cit., p. 882, Tít. [267], Lv. VI; CFA, $P M H-L G$, op. cit., p. 809, Tít. [163].

${ }^{42}$ CFCM, $P M H-L G$, op. cit., p. 924, Tít. [233], Lv. VI; CFCR, $P M H-L G$, op. cit., p. 879, Tít. [246], Lv. VI. 


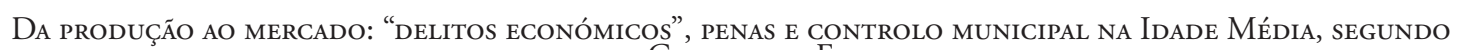
O TESTEMUNHO DOS COSTUMES E Foros PORTUGUeSES

Maria Alice da Silveira Tavares

narem, devendo assim ser instalados, de preferência, nos arredores das vilas. ${ }^{43}$ Esses ofícios implicavam o uso do carvão e do fogo, contribuindo para a proliferação de incêndios, colocando em perigo as populaçôes e os seus bens. Além disso, essas profissões deixavam rastos de sujidade, facilitando a acumulação de resíduos, nas áreas envolventes e nas ruas dos concelhos, pondo em causa a higiene e a salubridade dos habitantes. As atividades "industriais" concentravam-se também em outros lugares para além das oficinas, no interior das casas dos artesãos, ao ocupar as ruas e os espaços públicos circundantes às suas habitaçôes, sujando e impossibilitando a passagem de mercadorias, animais e pessoas.

Por outro lado, não é de excluir a hipótese de que esta medida fosse mais uma forma encontrada pelos municípios para supervisionar com mais facilidade os mesteres e os agentes comerciais, ao concentrá-los em determinados espaços dos concelhos (bancadas, tendas, mercados, açougues, fangas, ${ }^{44}$ por exemplo), ficando assim mais fácil inspecionar as matérias-primas, o fabrico, as vendas e os preços das mercadorias, bem como multar e cobrar tributos. No entanto, os esforços das autoridades locais nem sempre se fizeram sentir, uma vez que os mesteirais tinham o hábito de não seguir os "marcos" dos concelhos.

Partindo do pressuposto anterior, estamos defronte de mais uma medida de controlo da parte das autoridades camarárias, cuja ação se fez também sentir nas transaçôes comerciais levadas a cabo nas ruas das vilas e no interior das casas dos seus habitantes, como podemos depreender através de uma simples leitura dos regulamentos costumeiros. Estas últimas deviam estar autorizadas e ainda eram inspecionadas, como acontecia em Castelo Bom e Beja. ${ }^{45}$ Esta forma de comércio estava contudo proibida nas vilas de Riba-Côa. ${ }^{46}$ Já em Torres Novas, as padeiras que vendessem os seus pães em casa eram taxadas com um dinheiro diário ao açougueiro ${ }^{47} \mathrm{e}$ um dinheiro semanal ao mordomo, que devia ser pago ao Sábado. ${ }^{48}$

Através dos costumes e foros objeto de estudo, podemos constatar que os concelhos foram ainda mais longe ao estipular outras normativas sobre as mercadorias que eram colocadas ao dispor das populaçóes, os tributos e os profissionais que podiam vender, como, acontecia em Évora, Beja e Santarém..$^{49}$ Analisemos, uma vez mais, o caso das padeiras. Estas eram portanto obrigadas a comercializar os pães nos açougues. ${ }^{50}$ Se as padeiras eborenses es-

\footnotetext{
${ }^{43}$ Veja-se Díez de Salazar, Luís. La industria del hierro en Guipúzcoa (siglos XIII — XVI). (Aportación al estudio de la industria urbana). En la España Medieval, Madri, n. 6, p. 275, 1985. Disponível em: <http://www. ucm.es/BUCM/revistas/ghi/02143038/articulos/ELEM85851202251A.PDF>. Acesso em: 15 jul. 2007.

${ }^{44}$ Mercados especializados, especialmente, no comércio de cereais.

${ }^{45}$ CFCB, $P M H-L G$, op. cit., p. 772, Tít. [235]; CFB, $P M H-L G$, op. cit., p. 60, Tít. [73].

${ }^{46}$ CFCB, PMH - LG, op. cit., p. 772, Tít. [236]; CFCM, PMH - LG, op. cit., p. 917, Tít. [175], Lv. V; CFCR, $P M H-L G$, op. cit., p. 872, Tít [188], Lv. V; CFA, $P M H-L G$, op. cit., p. 827, Tít. [326].

${ }^{47}$ CFTN, $P M H-L G$, op. cit., p. 94, Tít. [84].

${ }^{48}$ CFTN, $P M H-L G$, op. cit., p. 94, Tít. [85].

${ }^{49}$ CTCE, $P M H-L G$, op. cit., p. 84, Tít. [26]; CGCA, PMH - LG. Olisipone: IUSSU Academiae Seicentiarum Olisiponensis, MDCCCLVI. v. II, p. 76, Tít. [27].

${ }^{50}$ CTCE, Portvgaliae Monumenta Historica, op. cit., p. 84, Tít. [26]; CGCA, PMH - LG, op. cit., p. 76, Tít. [27]; CSCVNA, PMH - LG. Olisipone: IUSSU Academiae Seicentiarum Olisiponensis, MDCCCLVI. v. II, p. 49, Tít. [57].
} 


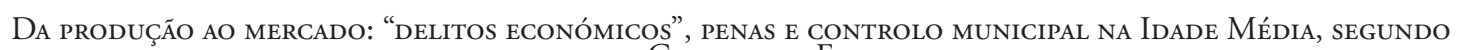
O TESTEMUNHO DOS Costumes e Foros PORTUGUeSES

Maria Alice da Silveira Tavares

tivessem interessadas em vender as suas mercadorias na vila, deviam pagar um dinheiro por cada cesto de pão. ${ }^{51}$ A situação era semelhante para as padeiras de Beja..$^{52}$ Já as vendedoras de legumes de Torres Novas pagavam a açougagem, ${ }^{53}$ em funçấo dos meios de transporte, cavalos ou burros, usados para acudirem ao açougue, e do tipo de cestos, com ou sem arco. ${ }^{54}$

Em Riba-Côa, procedia-se de maneira semelhante. Todas as vendas, sobretudo de determinados produtos, como a carne, o peixe e o pão, só se podiam realizar em locais próprios, como os mercados, até ao pôr do sol..$^{55}$ Abria-se, porém, uma exceção para o vinho, que podia ser comercializado em qualquer sítio, mesmo nas casas particulares. Isso tudo para contrariar a tendência de vender bens de primeira necessidade em ambientes privados, propícios a práticas fraudulentas, pois escapavam com mais facilidade aos olhares das autoridades locais. O objetivo principal era controlar as caraterísticas e a qualidade dos produtos, os preços, as medidas e os pesos usados nos concelhos. Daí ser também importante concentrar todos os comerciantes em espaços reservados ao comércio. A vila de Alfaiates foi ainda mais longe ao legislar, com mais minúcia, sobre os açougues, sobretudo, no que respeita aos produtos e a forma como deviam ser transacionados. Deste modo, era obrigatório colocar as mercadorias à venda em cima das mesas à vista de todos. Durante a noite, as mesas eram recolhidas, embora fosse proibido guardá-las fora do telhado ou levá-las para casa. O comércio de lenha não era permitido no açougue, salvo no mês de Junho, nos dias de São Joáo e Sáo Pedro. ${ }^{56}$ $\mathrm{O}$ mesmo se diga das fangas de Beja, pois os produtos dominantes deviam ser os cereais, o pão, a farinha, as nêsperas, a bolota e os frutos secos. ${ }^{57}$ Já as enxercas de Santarém estavam reservadas para a venda de carne, especialmente de porco, ${ }^{58}$ ao passo que a zona da ribeira se destinava ao comércio de peixe. ${ }^{59}$

Os costumes e foros não só definiram as mercadorias e as zonas de comércio, como acabamos de comprovar, mas também os preços e tributos que as vendas acarretavam, ape-

\footnotetext{
${ }^{51}$ CTCE, $P M H-L G$, op. cit., p. 84, Tít. [26].

${ }^{52} \mathrm{CFB}, P M H-L G$, op. cit., p. 59, Tít. [70].

${ }^{53}$ Açougagem ou brancagem consiste também num imposto indireto que incidia sobre o consumo de mercadorias. MARQUES, António de Oliveira. Fazenda pública — Na Idade Média. In: SERRÃO, Joel (Dir.). Dicionário de História de Portugal. Porto: v. II, Livraria Figueirinhas, 1963-1968, p. 533-525.

${ }^{54}$ CFTN, PMH - LG, op. cit., p. 94-95, Tít. [86].

55 GARCÍA DE VALDEAVELLANO, Luís. El Mercado. Apuntes para su estudio en León y Castilla durante la Edad Media. Anuario de Historia del Derecho Español, Madri, n. 8, p. 201-405, 1931, p. 327; TORQUEMADA, María Jesús. Algunos aspectos de la regulación sobre consumo en la Baja Edad Media castellana: pesas y medidas, ocupación de locales y horarios de comercio. Revista de la Facultad de Derecho de la Universidad Complutense, op. cit., p. 461.

${ }^{56}$ CFA, PMH - LG, op. cit., p. 835, Tít. [415].

${ }^{57} \mathrm{CFB}, P M H-L G$, op. cit., p. 59, Tít. [68].

${ }^{58}$ CFS, PMH - LG. Olisipone: IUSSU Academiae Seicentiarum Olisiponensis, MDCCCLVI. v. II, p. 30, Tít. [139]; CFBb, RODRIGUES, Maria Celeste Matias. Dos Costumes de Santarém. Tese (Mestrado em Linguística Portuguesa Histórica) — Faculdade de Letras da Universidade de Lisboa, Lisboa, 1992, p. 141, Tít. [139].

${ }^{59}$ CFS, $P M H-L G$, op. cit., p. 32, Tít. [155] e p. 24, Tít. [73].
} 


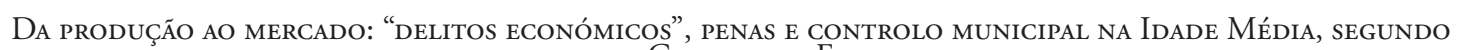
O TESTEMUNHO DOS COSTUMES E Foros PORTUGUESES

Maria Alice da Silveira Tavares

sar de não serem ponto de análise neste trabalho, requerendo um estudo mais minucioso, $a$ posteriori. Neste sentido, torna-se fundamental afixar e manter o equilíbrio dos preços das mercadorias, com o objetivo de assegurar o abastecimento adequado das populações para que todos pudessem adquirir, pelo menos, os bens essenciais para o dia a dia, nas melhores condiçôes. Ou seja, taxar "los precios es una garantia de paz social", ${ }^{60}$ nas palavras de Bonachía Hernando. Por outro lado, torna-se pertinente frisar que as tabelas dos preços já deixavam uma margem de lucro que compensasse o trabalho e os investimentos dos mesteirais e dos comerciantes, sem descurar o bem-estar dos consumidores.

Quanto aos pesos e às medidas, deviam pertencer aos concelhos, como acontecia em Évora, devendo ser confiadas a um indivíduo de confiança para os guardar. ${ }^{61}$ As autoridades camarárias, como acabamos de ver, pretendiam assim evitar fraudes e quaisquer manipulações desses instrumentos que pudessem ser nocivas nas trocas comerciais, ao prejudicar o correto abastecimento e enganar os compradores.

Além dos magistrados municipais de confiança, os concelhos dispunham de outros encarregados, tais como os "ochaveiros” nas vilas de Riba-Côa e os almotacés, em Santarém, Évora e Beja. Estes tinham a função de controlar e vigiar o cumprimento das normativas locais, superintendendo, por exemplo, as transaçóes de mercadorias, os espaços de mercado e as condições de salubridade. ${ }^{62}$ Os almotacés de Santarém chegavam inclusive a verificar o peso e a qualidade dos pães. ${ }^{63}$ Por outro lado, havia ainda a questão da segurança, necessária para a manutenção da "paz de mercado", ${ }^{64}$ visto que as áreas comerciais, como qualquer espaço público, facilitavam o convívio, as trocas e os negócios, ao mesmo tempo, que propiciavam rixas e conflitos. Neste sentido, as autoridades concelhias apostaram num conjunto de medidas próprias, nas quais não nos iremos deter com pormenor, que consistiram, sobretudo, na aplicação de coimas, outras formas de coação aos delinquentes ${ }^{65}$ e no policiamento

${ }^{60}$ BONACHÍA HERNANDO, Juan Antonio. Abastecimiento urbano, mercado local y control municipal: la provisión y comercialización de la carne en Burgos (siglos XV). Espacio, Tiempo y Forma. Serie III. Historia Medieval, op. cit., p. 140.

${ }^{61}$ CTCE, PMH - LG, op. cit., p. 59, Títs. [34] e [35]; GONÇALVES, Iria. Defesa do consumidor na cidade medieval: os produtos alimentares (Lisboa — séculos XIV-XV). Arquipélago. Revista da Universidade dos Açores, op. cit., p. 40.

${ }^{62}$ CTCE, PMH - LG, op. cit., p. 84, Tít. [26]. Veja-se, BONACHÍA HERNANDO, Juan Antonio. Abastecimiento urbano, mercado local y control municipal: la provisión y comercialización de la carne en Burgos (siglos XV). Espacio, Tiempo y Forma. Serie III. Historia Medieval, op. cit., p. 100-101.

${ }^{63}$ BRANDÁO, Zeferino, Monumentos e lendas de Santarém, op. cit., p. 408, Tít. [229]. Leia-se, BONACHÍA HERNANDO, Juan Antonio. Abastecimiento urbano, mercado local y control municipal: la provisión y comercialización de la carne en Burgos (siglos XV). Espacio, Tiempo y Forma. Serie III. Historia Medieval, op. cit., p. 100-101.

${ }^{64}$ Consiste num estatuto jurídico de comércio que visa a existencia de una peculiar del mercado, de una reglamentación que supone determinadas autoridades y funcionarios y ciertas obligaciones por parte de los que acuden al mercado. GARCÍA DE VALDEAVELLANO, Luís. El Mercado. Apuntes para su estudio en León y Castilla durante la Edad Media. Anuario de Historia del Derecho Español, op. cit., p. 295-296.

${ }^{65}$ CFCB, $P M H-L G$, op. cit., p. 767, Tít. [197]; CFCM, $P M H-L G$, op. cit., p. 931, Tít. [310], Lv. VIII; 


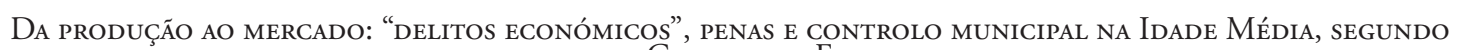
O TESTEMUNHO DOS COSTUMES E Foros PORTUGUESES

Maria Alice da Silveira Tavares

das cidades e dos locais reservados ao comércio levado a cabo por funcionários municipais, como forma de prevenção.

\section{Conclusão}

Em suma, falar de "delitos económicos" pressupõe um desafio, visto que se trata de uma questão que se mantém em aberto e carece de um estudo mais aprofundado para a Idade Média portuguesa, principalmente, com base em fontes de cariz jurídico, tais como os regulamentos dos concelhos (posturas, atas de vereação, etc.). Para realizarmos este estudo, optamos exclusivamente pelo uso dos costumes e foros para compreender, por um lado, os crimes que se levaram a cabo contra a economia municipal e, por outro lado, refletir e dar a conhecer as molduras penais e as medidas de controlo definidas pelo poder local. Neste sentido, as autoridades camarárias procuraram respostas e soluçôes para os conflitos que advinham de práticas antieconómicas, controlando a produção e a colocação dos produtos no mercado, com o fim de garantir a qualidade dos mesmos e o bom abastecimento dos concelhos. Porém, nem sempre essas normas terão sido eficazes, uma vez que podemos encontrar nos regulamentos costumeiros selecionados rúbricas sistemáticas a chamar a atenção para este tipo de criminalidade.

Apesar das dificuldades que essas fontes nos proporcionam, são primordiais para o conhecimento do funcionamento das atividades económicas locais, apresentando-nos um vasto leque de possibilidades de estudo, entre as quais os "delitos económicos", ponto nuclear de reflexão neste texto. Todavia, partirmos do pressuposto — "delitos económicos" —, acarreta os seus riscos, uma vez que estamos diante de um conceito operativo atual, impensável, à partida, de ser aplicado à realidade medieval, embora possamos inferir uma clara noção da parte das populaçôes medievas da existência de crimes e transgressóes que pudessem ocorrer durante o desenvolvimento das atividades económicas, principalmente a indústria e o comércio, chegando ao ponto de estas praxis serem regulamentadas e sancionadas nos ordenamentos costumeiros. Neste sentido, apercebemo-nos que o campo de atuação das autoridades municipais centrava-se em determinar normas que visavam controlar e minimizar a fraude, o açambarcamento, a especulação e outros delitos.

Podemos, portanto, chegar à conclusão de que as normativas costumeiras versam um conjunto de medidas de combate à fraude económica e fiscal e a outras condutas pouco propícias ao bom funcionamento da economia e ao provimento das comunidades municipais, sancionando os mesteirais e os comerciantes que enganassem os consumidores e fugissem aos impostos no exercício das suas actividades, desobedecendo aos "marcos" dos concelhos, ou seja,

CFCR, PMH - LG, op. cit., p. 888, Tít. [324], Lv. VIII; CFA, PMH - LG, op. cit., p. 813, Tít. [197]. Veja-se GARCÍA DE VALDEAVELLANO, Luís. El Mercado. Apuntes para su estudio en León y Castilla durante la Edad Media. Anuario de Historia del Derecho Español, op. cit., p. 257. 


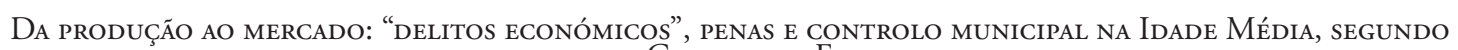
O TESTEMUNHO DOS COSTUMES E FOROS PORTUGUESES

Maria Alice da Silveira Tavares

aos regulamentos "industriais" e "comerciais" afixados pelos mesmos, incentivando também as pessoas a reclamarem e a denunciarem esses casos quando se sentissem prejudicadas. As populaçôes podiam, desta forma, ter acesso aos produtos com qualidade e em boas condiçôes para os adquirirem. Deste modo, os concelhos procuraram garantir o abastecimento e o acesso ao consumo às suas gentes, assumindo um papel intervencionista e protecionista.

Siglas

CFA - Costumes e Foros de Alfaiates

CFB - Costumes e Foros de Beja

CFCB - Costumes e Foros de Castelo Bom

CFCM - Costumes e Foros de Castelo Melhor

CFCR - Costumes e Foros de Castelo Rodrigo

CFS - Costumes e Foros de Santarém

CFTN - Costumes e Foros de Torres Novas

CGCA - Costumes de Garvão comunicados d'Alcácer

CSCVNA - Costumes de Santarém comunicados a Villa Nova d'Alvito

CTCE - Costumes de Terena comunicados d'Évora

PMH - LC - Portvgaliae Monumenta Historica - Leges et Consuetudines

Tít. - Título

Fontes e referências bibliográficas

Fontes

BRANDÁO, Zeferino. Monumentos e Lendas de Santarém. Lisboa: David Corazzi — Editor, 1883.

Portvgaliae Monumenta Historica. Leges et Consuetudines. V. 1 e 2. Olisipone: IUSSU Academiae Seicentiarum Olisiponensis, MDCCCLVI.

RODRIGUES, Maria Celeste Matias. Dos vostumes de Santarém. Tese (Mestrado em Linguística Portuguesa Histórica) — Faculdade de Letras da Universidade de Lisboa, Lisboa, 1992.

\section{Bibliografia}

AGUADÉ NIETO, Santiago; CABAÑAS, María Dolores. Comercialización y sociedad urbana en la Castilla medieval. La comercialización de la carne en Cuenca (1177-1500). Anuario de Estudios Medievales, Madri, n. 14, p. 487-423, 1984. 


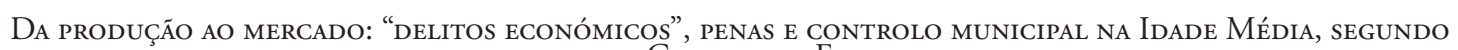
O TESTEMUNHO DOS COSTUMES E FOROS PORTUGUESES

Maria Alice da Silveira Tavares

BERNAL PEÑA, José. Golfines y asesinos. Elementos y motivaciones de las conductas violentas en Murcia durante el siglo XIV. MVRGETANA, Murcia, n. 125, p. 61-82, 2011. Disponível em: <http://dialnet.unirioja.es/servlet/articulo?codigo=3768237>. Acesso em: 9 mar. 2013.

BONACHÍA HERNANDO, Juan Antonio. Abastecimiento urbano, mercado local y control municipal: la provisión y comercialización de la carne en Burgos (siglos XV). Espacio, Tiempo y Forma. Serie III. Historia Medieval, Madri, n. 5, p. 140-141, 1992. Disponível em: <http://e-spacio.uned.es/fez/eserv.php?pid=bibliuned:ETFFB773A7E-2555-6065-07F717991CC80854\&dsID=Documento.pdf>. Acesso em: 6 abr. 2013.

BUENO DOMÍNGUEZ, María Luisa. Contactos con la vida material en Zamora. Siglos XII-XV. Espacio, Tiempo y Forma. Seria II, Historia Medieval, Madri, n. 18, p. 39-58, 2005. Disponível em: <http://e-spacio.uned.es/fez/eserv.php?pid=bibliuned:ETF43772BD60E92-A2F8-7C0B-FAED390306EA\&dsID=Documento.pdf>. Acesso em: 9 set. 2011.

CANTERA MONTENEGRO, Enrique. La carne y el pescado en el sistema alimentario judío en la España Medieval. Espacio, Tiempo y Forma. Serie III. Historia Medieval, Madri, n. 16, p. 13-51, 2003. Disponível em: <http://e-spacio.uned.es/fez/eserv. php?pid=bibliuned:ETF366B37E9-B682-D954-BEFD-7F1F77C2556E\&dsID=PDF>. Acesso em: 12 fev. 2011.

CINTRA, Luís Filipe Lindley. A linguagem dos Foros de Castelo Rodrigo e seu confronto com a dos Foros de Alfaiates, Castelo Bom, castelo Melhor, Coria, Cáceres e Usagre. Contribuição para o estudo do leonês e do galego — português do século XIII. Lisboa: INCM, 1984.

Delitos antieconómicos. Ed. Polícia de Segurança Pública - Escola Prática. Torres Novas: Escola Prática, 2004.

DÍEZ DE SALAZAR, Luís. La industria del hierro en Guipúzcoa (siglos XIII-XVI). (Aportación al estudio de la industria urbana). En la España Medieval, Madri, n. 6, p. 251276, 1985. Disponível em: <http://www.ucm.es/BUCM/revistas/ghi/02143038/articulos/ ELEM85851202251a.pdf>. Acesso em: 15 jul. 2007.

ESCRIBANO ABAD, José Luís. La regulación del mercado alimentario: el caso de la Guadalajara bajomedieval. Espacio, Tiempo y Forma. Serie III. Historia Medieval, Madri, n. 21, p. 109-137, 2008. Disponível em: <http://e-spacio.uned.es/fez/eserv.php?pid=bibliune d:ETFSerieIII2008n21-10510\&dsID=Documento.pdf >. Acesso em: 21 jul. 2001.

GARCÍA DE VALDEAVELLANO, Luís. El Mercado. Apuntes para su estudio en León y Castilla durante la Edad Media. Anuario de Historia del Derecho Español, Madri, n. 8, p. 201-405, 1931.

GOICOLEA JULIÁN, Fco Javier. Mundo urbano y actividades económicas en la Rioja Alta bajomedieval. Espacio, Tiempo y Forma. Serie III. Historia Medieval, Madri, n. 11, p. 243-283, 


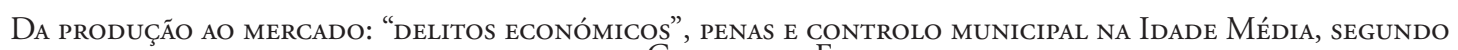
O TESTEMUNHO DOS COSTUMES E FOROS PORTUGUESES

Maria Alice da Silveira Tavares

1998.Disponívelem:<http://e-spacio.uned.es/fez/eserv.php?pid=bibliuned:ETF61C966A9D2DF-DF0B-18EE-A0DFE24D1D0A\&dsID=Documento.pdf>. Acesso em: 12 dez. 2012.

GONÇALVES, Iria. Defesa do consumidor na cidade medieval: os produtos alimentares (Lisboa - séculos XIV-XV). Arquipélago. Revista da Universidade dos Açores, Ponta Delgada, n. 1, p. 29-48, 1995. Disponível em: <https://repositorio.uac.pt/bitstream/10400.3/501/1/ IriaGoncalves_p29-48.pdf >. Acesso em: 30 out. 2012.

GONZÁLEZ ARCE, José Damián. El artesanado en los Fueros del Reino de Murcia. Anuario de Estudios Medievales, Madri, n. 25, p. 81-126, 1995.

HINOJOSA MONTALVO, José. Poder municipal y abastecimiento de carne en la gobernación de Orihuela a fines de la Edad Media. Miscelánea Medieval Murciana, Murcia, n. 21-22, p. 157-170, 1997-1998. Disponível em: <http://dialnet.unirioja.es/servlet/ articulo?codigo=52955>. Acesso em: 30 dez. 2012.

JARA FUENTE, José Antonio. Élites urbanas: las políticas comerciales y de mercado como formas de prevención de conflictos y de legitimación del poder (la veda del vino en Cuenca en la Baja Edad Media). Brocar: cuadernos de investigación histórica, Logroño, n. 21, p. 119133, 1998. Disponível em: <http://dialnet.unirioja.es/servlet/articulo?codigo=227748>. Acesso em: 30 dez. 2012

LÓPEZ VILLALBA, José Miguel. Política local y abastecimiento urbano: el pescado en Guadalajara en la Baja Edad Media. Studia Historica. Historia Medieval, Salamanca, n. 25, p. 221-244.

LOZANO GRACIA, Susana. Fraudes y licencias en el comercio aragonés a mediados del siglo XV. Aragón en la Edad Media, Zaragoza, n. 11, p. 117-162, 2004. Disponível em: $<$ http://dialnet.unirioja.es/servlet/articulo?codigo=1183941 >. Acesso em: 4 abr. 2012.

MARQUES, António de Oliveira. Fazenda pública — Na Idade Média. In: SERRÃO, Joel (Dir.). Dicionário de História de Portugal. Porto: v. II, Livraria Figueirinhas, 1963-1968, p. 533-525.

MARTÍNEZ MARTÍNEZ, Julio Gerardo. Los oficios menestrales en los Fueros de Cáceres. Anuario de la Facultad de Derecho, Cáceres, n. 3, p. 133-165, 1984-1985.

MENDO CARMONA, Concepción. La industria del cuero en la Villa y tierra de Madri a finales de la Edad Media. Espacio, Tiempo y Forma, Serie III. Historia Medieval, Madri, n. 3, p. 181-211, 1990. Disponível em: <http://e-spacio.uned.es/fez/eserv. php?pid=bibliuned:etf859480da-15d9-2fde-f0be-f027b39be50b\&dsid=documento.pdf . Acesso em: 30 dez. 2012.

SILVA, Nuno Espinosa Gomes da. História do Direito Português. Lisboa: Associação Académica da Faculdade de Direito, 1971. 
Da produção ao mercado: "Delitos económicos", penas e Controlo municipal na Idade Média, SEgundo O TESTEMUNHO DOS COSTUMES E Foros PORTUGUESES

Maria Alice da Silveira Tavares

TORQUEMADA, María Jesús. Algunos aspectos de la regulación sobre consumo en la Baja Edad Media castellana: pesas y medidas, ocupación de locales y horarios de comercio. Revista de la Facultad de Derecho de la Universidad Complutense, Madri, n. 84, p. 447-468, 1992-1994.

VIANA, Mário. Os vinhedos medievais de Santarém. Cascais: Patrimonia Histórica, 1998. 